\title{
Assessment of Strength of Hollow Concrete Blocks with Holes Reinforced with Half Portion of Coconut Shells
}

\author{
Anu S Das*, Ansu V, Megha P, Nithin M Thomas, Sachin A K \\ Department of Civil Engineering, Government Engineering College Kozhikode, Kerala, India \\ *Email: anusdaso07@gmail.com
}

ARTICLE INFORMATION

DOI: $10.15415 /$ jotitt.2018.62008

Keywords: Building construction, Hollow concrete blocks, Coconut shells, Sustainable development, Environmental protection.

\begin{abstract}
Natural building materials are diminishing day by day. Hence economical alternatives of natural building materials are necessary for sustainable development. Hollow concrete block was developed to reduce the use of natural building materials. Agricultural waste products like coconut shells from coconut industry have disposal problems causing environmental concerns. Various studies were done in the past, replacing a portion of the natural aggregates with broken coconut shells for manufacturing the hollow concrete blocks. In this study, we have developed a new method of forming the holes of hollow concrete blocks by placing stacks of half portion of coconut shells at the bottom with convex surface upwards to reinforce the holes by arch action. The results show that the coconut shell reinforced hollow concrete blocks have better strength as compared to open graded hollow concrete blocks available in the market.
\end{abstract}

\section{Introduction}

Bricks and stones are the conventional building blocks for the load-bearing structures. These conventional building materials and its raw materials are depleting quickly. Hence for sustainable development, alternative cost effective building blocks were developed. Harmon S. Palmer developed the first hollow concrete block in 1890 and patented the design in 1900. Hollow concrete blocks may have one or more hollow cavities. Palmer's blocks were of size 8 inch $(20.3 \mathrm{~cm}) \times 10$ inch $(25.4 \mathrm{~cm}) \times 30$ inch $(76.2 \mathrm{~cm})$, and they were so heavy to lift. By 1905 , about 1,500 companies were manufacturing concrete blocks in United States [1]. Hollow building blocks, are famous in the construction industry because of its economy.

\section{Literature review}

Coconut is grown in over 93 countries in the world. Coconut shells presents serious disposal problems for local environment and is an agricultural waste from coconut industries. Countries having abundant coconut shell waste can use this as a potential building material in the 
construction industry [2]. This will dispose the waste coconut shells and reduce the cost of construction. Aggregates are an essential element of concrete used as a filler material to prevent shrinkage and provide stiffness. Researchers have done various studies to find suitable alternatives for natural aggregates. Coconut shell has high strength properties and high lignin content making weather resistant. Coconut shell has a low cellulose content because of which it absorb less moisture as compare to other agriculture waste and can be used in concrete as aggregates [3]. A previous study concluded that the coconut shells can be used as a lightweight aggregate for concrete to reduce cost and dispose abundant agricultural waste. It was also found out that the strength of concrete reduces as the percentage of coconut shell aggregate increases [4]. A study using the coconut shell as aggregate found out that by replacing $50 \%$ aggregate by broken coconut shells there is a reduction in cost between $9 \%$ to $11 \%$ and small reduction of strength between $10 \%$ to $20 \%$ [5]. Some researchers have used coconut shells as a partial replacement of coarse aggregate and found out that as the percentage of coconut shells increase the compressive strength decreases but the overall cost also reduces. They have further concluded that coconut shell can be used where lightweight concrete is required which will also protect the environment [6]. Another study found out that the combination of coconut shell as coarse aggregate and the broken palm kernel shells as fine aggregate in concrete reduce the material cost in construction [7]. Some studies have used broken coconut shell as a substitute for fine and coarse aggregate in hollow concrete blocks. In a study, researchers have used broken coconut shells and coconut fibre as a partial replacement of aggregate for making hollow concrete blocks and found out that appropriate coconut shell content produced workable concrete with satisfactory strength [8]. Further studies have found out that the compressive strength of hollow concrete blocks with the coconut shell and fibre attained was higher than the commercially available ones and their resistance to thermal conductivity was also better [9].

\section{Experimental procedure}

In all the previous studies as discussed in the previous section, it was found out that the coconut shells were broken into small pieces and used as aggregates. But we have developed a new method of forming the holes of hollow concrete blocks by placing stacks of half portion of coconut shells at the bottom with convex surface upwards with the hypothesis, it would increase its strength. Convex surface of coconut shells have natural dome shape structure which will reinforce the holes in the hollow blocks and takes higher compressive strength by arch action. We placed coconut shells in two stacks of four shells each as shown in the Fig. 1 and Fig. 2. This study tries to compare the strength of the hollow concrete blocks reinforced with coconut shells as compared to the commercially available hollow concrete blocks. The experiment covers design and development of a hollow concrete block with coconut shells and finding out the compressive strength, cost and water absorption. Open graded hollow concrete blocks having $40 \mathrm{~cm}$ length, $20 \mathrm{~cm}$ breadth and $20 \mathrm{~cm}$ height are available in the market with a mix proportion of 1:3:6 (1 cement: 3 sand: 6 aggregates of $6 \mathrm{~mm}$ nominal size) with water-cement ratio of o.5. Hence, we made hollow concrete blocks of the same size and mix, but forming the holes by placing stacks of half portion of coconut shells at the bottom with convex surface upwards to reinforce the holes. The diameter of coconut shell used for the experiment was $8 \mathrm{~cm}$ and the cement used in this study is 43 grade ordinary Portland cement. 


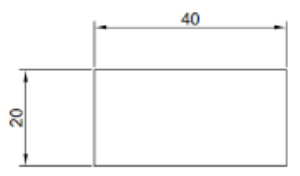

ELEVATION

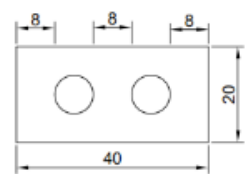

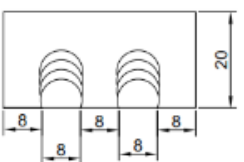

SECTION

\section{PLAN}

Figure 1: Design of coconut shell reinforced hollow concrete block

Fresh concrete is poured on top of the coconut shells in the mould in three layers so that holes are formed under the coconut shells. Each layer was tamped 25 times using tamping rod without affecting the position of coconut shells. We removed the mould after 24 hours, cured the blocks by immersing in water for 28 days and found the compressive strength. The photograph of the bottom portion of the hollow concrete block is shown in Fig. 3.

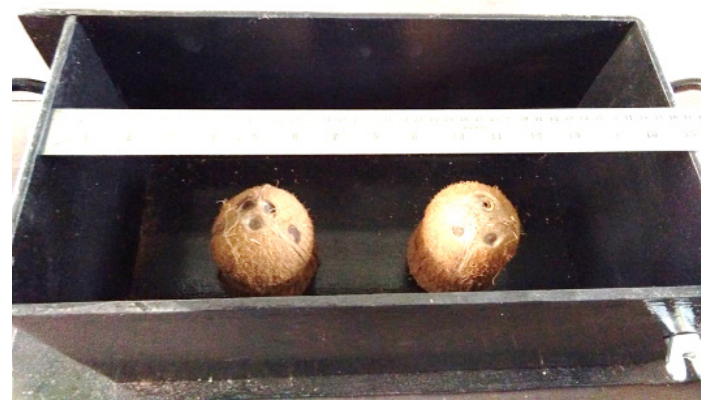

Figure 2: Placing of coconut shells in the mould

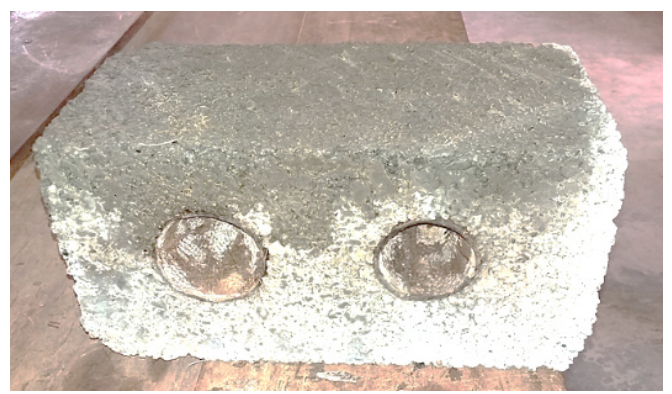

Figure 3: The photograph of the bottom portion of the moulded open graded hollow concrete block 


\section{Results and discussion}

Table 1 presents the rate analysis of the hollow concrete block with coconut shells and the hollow concrete block available in the market is done as per the Delhi schedule of rates
(DSR). The rate analysis shows that the cost of hollow concrete block with coconut shells is Rs. 50/- and the cost of hollow concrete block available in the market is Rs 51/-.

Table 1. Rate analysis of the hollow concrete blocks

\begin{tabular}{|c|c|c|c|c|c|}
\hline $\begin{array}{l}\text { DSR } \\
\text { Code }\end{array}$ & Description & Unit & Quantity & Rate & Amount \\
\hline & Details of cost for 1 Cubic meter & & & & \\
\hline 295 & Stone Aggregate of $6 \mathrm{~mm}$ nominal size & cum & 0.7000 & 1300.00 & 910.00 \\
\hline 2202 & $\begin{array}{l}\text { Carriage of Stone aggregate below } 40 \mathrm{~mm} \\
\text { nominal size }\end{array}$ & cum & 0.7000 & 103.77 & 72.64 \\
\hline 982 & Coarse sand (zone III) & cum & 0.3500 & 1200.00 & 420.00 \\
\hline 2203 & Carriage of Coarse sand & cum & 0.3500 & 103.77 & 36.32 \\
\hline 367 & Portland Cement & tonne & 0.0167 & 5700.00 & 95.19 \\
\hline 2209 & Carriage of Cement & tonne & 0.0167 & 92.24 & 1.54 \\
\hline 114 & LABOUR: Beldar & Day & 0.6000 & 368.00 & 220.80 \\
\hline 115 & Coolie & Day & 0.4000 & 368.00 & 147.20 \\
\hline 2 & $\begin{array}{l}\text { Hire charges of Concrete Mixer } 0.25 \text { to } \\
0.40 \text { cum with Hopper }\end{array}$ & Day & 0.0700 & 800.00 & 56.00 \\
\hline & Sundries & L.S & & & 150.00 \\
\hline & TOTAL & & & & 2109.69 \\
\hline & Add Water Charges@1\% & & & & 21.10 \\
\hline & TOTAL & & & & 2130.79 \\
\hline & Add CPOH@15\% & & & & 319.62 \\
\hline & Cost of 1 cum & & & & 2450.40 \\
\hline & Rounded & & & & 2450.00 \\
\hline & Cost Index $\quad \mathbf{3 7 . 2 5} \%$ & & & & 912.63 \\
\hline & Total with Cost index & $\begin{array}{l}\text { Rs./ } \\
\text { cum }\end{array}$ & & & 3362.63 \\
\hline & \multicolumn{5}{|l|}{ Details of cost for Designed Hollow blocks } \\
\hline & $\begin{array}{l}\text { Volume of Solid Concrete Blocks of size } \\
40 * 20 * 20 \mathrm{~cm}\end{array}$ & cum & 0.01600 & & \\
\hline & Less volume of 2 holes with coconut shells & cum & -0.00107 & & \\
\hline & Total cost of Designed Hollow blocks & cum & 0.01493 & 3362.63 & 50 \\
\hline
\end{tabular}




\begin{tabular}{|l|l|l|r|r|r|}
\hline & $\begin{array}{l}\text { Volume of Solid Concrete Blocks of size } \\
40 * 20 * 20 \mathrm{~cm}\end{array}$ & cum & 0.01600 & & \\
\hline & Less volume of 2 holes with coconut & cum & -0.00072 & & \\
\hline & Total cost of Hollow blocks in market & cum & 0.01528 & 3362.63 & $\mathbf{5 1}$ \\
\hline
\end{tabular}

We found the compressive strength of hollow concrete blocks as shown in Fig. 4. The blocks are placed for testing such that the coconut shells are at the bottom convex upwards to develop arch action. Table 2 presents the 28 day average compressive strength of the hollow concrete blocks. The average compressive strength of hollow concrete blocks reinforced with coconut shells was found to be $10.28 \mathrm{~N} / \mathrm{mm}^{2}$ and the average compressive strength of the hollow concrete blocks available in the market was found to be $6.17 \mathrm{~N} /$ $\mathrm{mm}^{2}$. Hence, results shows that the compressive strength of hollow concrete blocks increases by reinforcing it with the coconut shell. The water absorption of our designed hollow concrete blocks was found to be $7.8 \%$. As per IS 2185 water absorption of hollow blocks should not be over 10 percent by mass. Hence water absorption of hollow concrete block reinforced with the coconut shell is satisfactory.

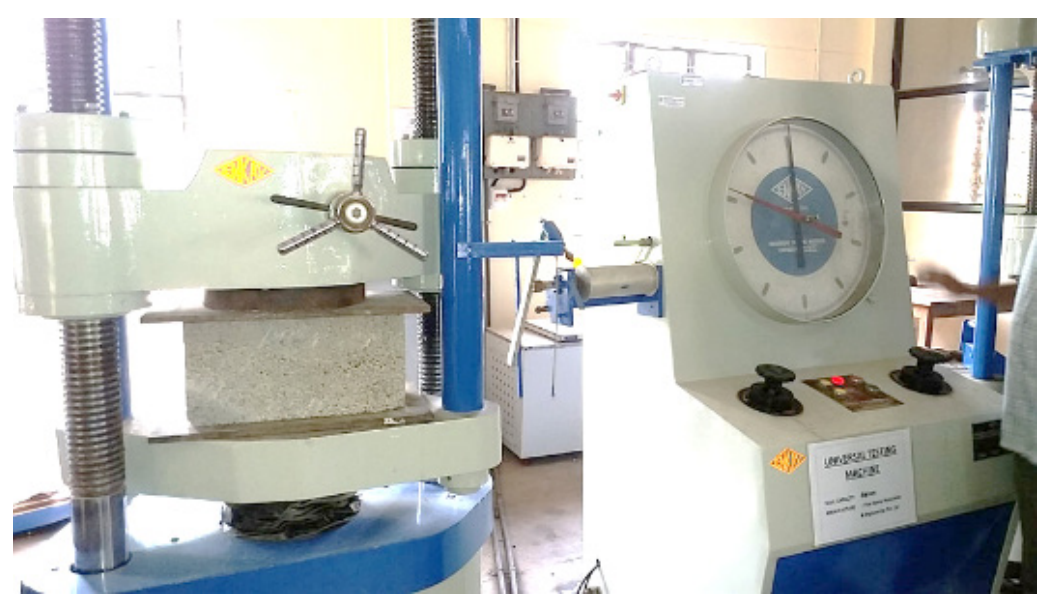

Figure 4: Testing of hollow concrete block

Table 2: Average compressive strength at 28 days

\begin{tabular}{|l|c|}
\hline Particulars & $\begin{array}{l}\text { Average compressive strength at 28 } \\
\text { days in N/mm² }\end{array}$ \\
\hline Hollow concrete block reinforced with coconut shells & $10.28 \mathrm{~N} / \mathrm{mm}^{2}$ \\
\hline Hollow concrete block available in the market & $6.17 \mathrm{~N} / \mathrm{mm}^{2}$ \\
\hline
\end{tabular}




\section{Conclusion}

In all the previous studies, the coconut shells were broken into small pieces and used as aggregates. In this study, we have developed a new method of forming the holes of hollow concrete blocks by placing stacks of half portion of coconut shells. The compressive strength of this designed hollow concrete blocks was found to be $32 \%$ higher than hollow concrete block available in the market. Moreover, by rate analysis we have found out that the cost of our hollow concrete blocks was found to be lesser than hollow concrete block available in the market. We also found the water absorption value of hollow concrete blocks to be satisfactory. Hence we conclude that the hollow concrete blocks reinforced with half portion of coconut shells is better than the traditional hollow concrete blocks available in the market.

\section{References}

[1] T. S. V. M. Thorat, M. Papal, V. Kacha and S. Gaikwad, "Hollow concrete blocks-A new trend," International Journal of Engineering \& Research, vol. 5, no. 5, pp. 9-26, 2015.

[2] G. Sangeetha, P. Nirmala, D. Pugazhselvi and K. Ramya, "Partial replacement of aggregate by coconut shell and cement by clay," International Journal of Engineering Science and Computing, vol. 6, no. 4, pp. 3442-3447, 2016.

[3] D. V. N. Kumar, P. M. G. Raju, P. Avinash, G. Rambabu, D. V. N. Kumar, and P. M. G. Raju, "A study on compressive strength of concrete by partial replacement of coarse aggregate with coconut shell and with addition of fiber", International Journal of Civil Engineering Research, vol. 8, no. 1, pp. 57-68, 2017.
[4] P. S. Kambli and S. R. Mathapati, "Compressive strength of concrete by using coconut shell”, IOSR Journal of Engineering, vol. 4 no. 4, pp. 1-7, 2014.

[5] D. Shradha, F. Hitali, P. Dode and S. Varpe, "Sustainable concrete by partially replacing coarse aggregate using coconut shell”, Journal on Today's Ideas-Tomorrow's Technologies, vol. 2, no. 1, pp. 41-54, 2014.

[6] Y. N. Sonawane and C. J. Chitte, "Waste coconut shell as a partial replacement of coarse aggregate in concrete mixAn experimental study", International Journal of Science and Research, vol. 5, no. 4, pp. 649-651, 2016.

[7] S. A. Tukiman and Mohd. Sabarudin, "Investigate the combination of coconut shell and grained palm kernel to replace aggregate in concrete: A technical review", in Proceeding of National Conference on Postgraduate Research (NCON-PGR) 2009, 1st October 2009, UMP Conference Hall, Malaysia.

[8] T. U. Ganiron, "Sustainable management of waste coconut shells as aggregates in concrete mixture," Journal of Engineering Science and Technology Review, vol. 6, no. 5, pp. 7-14, 2013.

[9] T. U. Ganiron, N. Ucol-Ganiron, and T. U. Ganiron III, "Recycling of waste coconut shells as substitute for aggregates in mix proportioning of concrete hollow blocks," Scientific Publishing House "DARWIN", pp. 107123, 2017. 